\title{
Arctic plant remains of Weichselian age from the Danish North Sea
}

\author{
Ole Bennike, Jørgen O. Leth, Jørn Bo Jensen, Niels Nørgaard-Pedersen and Steen Lomholt
}

The North Sea is a large, shallow epicontinental sea dominated by a sandy bottom that reflects a high-energy environment. Little is known about the environmental history of the Danish part of this large area during the Weichselian, the last ice age. Parts of it were glaciated during the last glacial maximum and probably also during older glaciations. Shallow parts were dry land, and deeper parts were covered by the sea during ice-free intervals. Large, partly ice-dammed lakes also existed.

Three remains of walrus (Odobenus rosmarus) have been radiocarbon dated (Möhl 1985; Kim Aaris-Sørensen, unpublished). One of the finds was dated to $c .35$ cal. ka BP, whereas the two others finds gave somewhat younger ages of c. 30 cal. ka BP (Table 1 ).

Knudsen (1985) described the stratigraphy of sediment cores from the western part of the Danish North Sea. From the Roar 41 core, she reported on Eemian deposits overlain by Weichselian marine deposits with an Arctic or BoreoArctic foraminiferal fauna. An age of 30-50 cal. ka BP was suggested for this deposit by Larsen et al. (2009, fig. $8 \mathrm{H}$ ). Leth (1998) obtained three radiocarbon ages of 43-45 cal. ka BP on marine bivalve shells from two vibrocores from Jyske Rev.

In connection with mapping of sand and gravel deposits in 2012, a number of $6 \mathrm{~m}$ long vibrocores were collected by the Geological Survey of Denmark and Greenland (GEUS). During description of the sediment cores, remains of plants were noted; most of them were early Holocene. However, a few samples from two sediment cores contained macrofossils of Arctic plants and two samples were dated. The aim of this paper is to report on these ages and their implications. The locations of the coring sites are shown in Fig. 1.

\section{Material and methods}

Sediment coring was carried out with a vibrocorer with a $6 \mathrm{~m}$ long, $10 \mathrm{~cm}$ wide steel core barrel with a PVC tube mounted. Coring positions were selected from high-resolution, shallow seismic profiles. The cores were collected in PVC tubes and cut into $1 \mathrm{~m}$ long sections and shipped to GEUS, where they were split and described. A few 1-2 kg samples with plant remains were wet sieved and the residue left on the sieves was analysed using a dissecting microscope. Two samples of terrestrial plant remains were dried and dated by radiocarbon accelerator mass spectrometry.

\section{A Late Weichselian deposit}

Lithological logs of the cores are shown in Fig. 2. NS 12-213 consists of $100 \mathrm{~cm}$ of Holocene marine silt and very finegrained sand, underlain by $178 \mathrm{~cm}$ indistinctly laminated clay and silt, $180 \mathrm{~cm}$ of alternating layers of fine-grained sand, medium-grained sand and silt, $15 \mathrm{~cm}$ silt and $71 \mathrm{~cm}$ of alternating layers of fine-grained sand, medium-grained sand and silt. The deposits below the marine unit were interpreted as Late Glacial. Plant remains were noted near the bottom of the core.

Remains of terrestrial plants include leaves of Salix herbacea, a leaf of Salix phylicifolia, a leaf of Betula nana, seeds of Empetrum nigrum, a seed of Lychnis flos-cuculi, a megaspore of Selaginella selaginoides and a stem of Distichium sp.

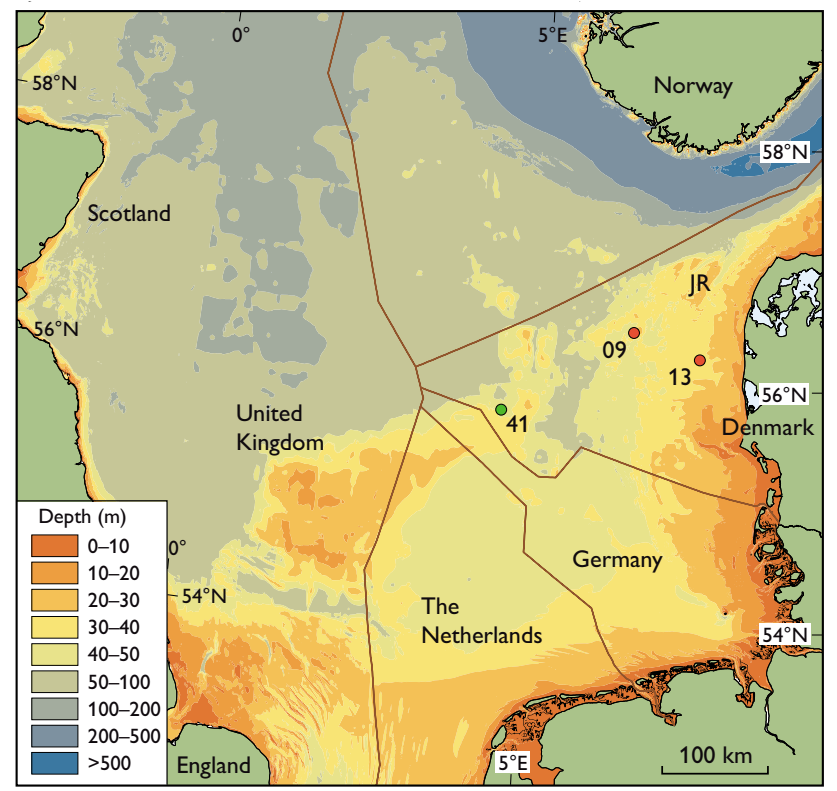

Fig. 1. Bathymetrical map of the North Sea. The dots show the locations of the studied sediment cores (13 = NS 12-2-13, 09 = NS 12-3-09). The green dot shows the location of core Roar 41 discussed by Knudsen (1985). JR: Jyske Rev. 
Table 1. Pre-Holocene radiocarbon ages from the Danish North Sea

\begin{tabular}{|c|c|c|c|c|c|c|c|}
\hline $\begin{array}{l}\text { Core } \\
\text { no. }\end{array}$ & N. Lat. & E. long. & $\begin{array}{c}\text { Laboratory } \\
\text { no. }\end{array}$ & Species & $\begin{array}{c}\text { Depth } \\
\text { b.c.t. }(\mathrm{cm})^{*}\end{array}$ & $\begin{array}{l}\text { Age }\left({ }^{14} C\right. \\
\text { years } B P)\end{array}$ & $\begin{array}{c}\text { Calibrated } \\
\text { age (years BP) }\end{array}$ \\
\hline NS $12-2-13$ & $56^{\circ} 15.862^{\prime}$ & $7^{\circ} 27.819^{\prime}$ & LuS-10493 & Salix herbacea & 542 & $10730 \pm 75$ & $12554-12746$ \\
\hline NS 12-2-09 & $56^{\circ} 28.478^{\prime}$ & $6^{\circ} 27.794^{\prime}$ & LuS-10494 & S. herbacea, D. octopetala & 495 & $30530 \pm 300$ & $33957-35010$ \\
\hline $562026^{\ddagger}$ & $56^{\circ} 39.3^{\prime}$ & $7^{\circ} 39.9^{\prime}$ & AAR-3291 & Spisula subtruncata & 230 & $39200 \pm 1100$ & $41136-44666^{\S}$ \\
\hline 562026 & $56^{\circ} 39.3^{\prime}$ & $7^{\circ} 39.9^{\prime}$ & AAR-3292 & Macoma balthica & 550 & $41500 \pm 1450$ & $42298-47250^{\S}$ \\
\hline \multirow[t]{4}{*}{562028} & $56^{\circ} 46.3^{\prime}$ & $7^{\circ} 33.2^{\prime}$ & AAR-3293 & Donax vittatus & 310 & $39300 \pm 1300$ & $40807-45085^{\S}$ \\
\hline & \multicolumn{2}{|c|}{ Off Esbjerg } & K-3727 & Odobenus rosmarus & & $24380 \pm 620$ & $27033-29417^{9}$ \\
\hline & c. $56^{\circ} 30^{\prime}$ & c. $7^{\circ}$ & K-3726 & Odobenus rosmarus & & $30880+1270$ & $31578-36940^{\circ}$ \\
\hline & c. $57^{\circ} 12^{\prime}$ & c. $8^{\circ} 28^{\prime}$ & K-5746 & Odobenus rosmarus & & $26700 \pm 1500$ & $27616-33475^{\mathrm{a}}$ \\
\hline
\end{tabular}

\footnotetext{
* Below core top.

† Calibrated according to the CALIB 7.0 program.

* Core numbers refer to the numbering system used by the marine geologists at GEUS.

$\S$ Leth (1998).

" Möhl (1985).

${ }^{a}$ K.Aaris-Sørensen, unpublished data.
}

(Table 2). Freshwater plants are represented by Potamogeton filiformis, and freshwater invertebrates are represented by Cristatella mucedo and Fredericella indica. Stems of Scorpidium scorpioides and Drepanocladus s.l. sp. are common; these mosses as well as Carex spp. probably grew in wet areas. A

NS $12-2-13$

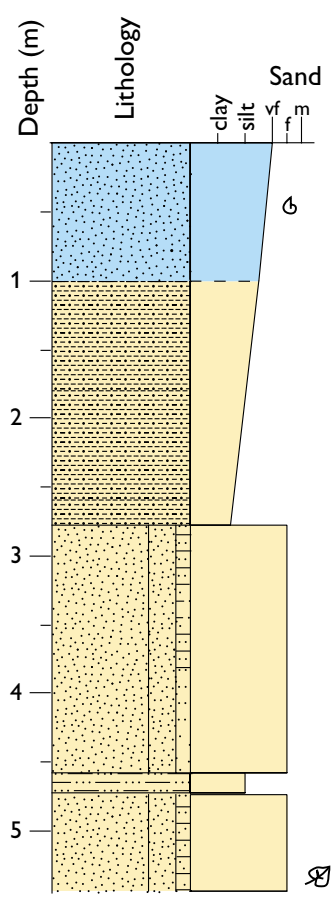

NS 12-3-09

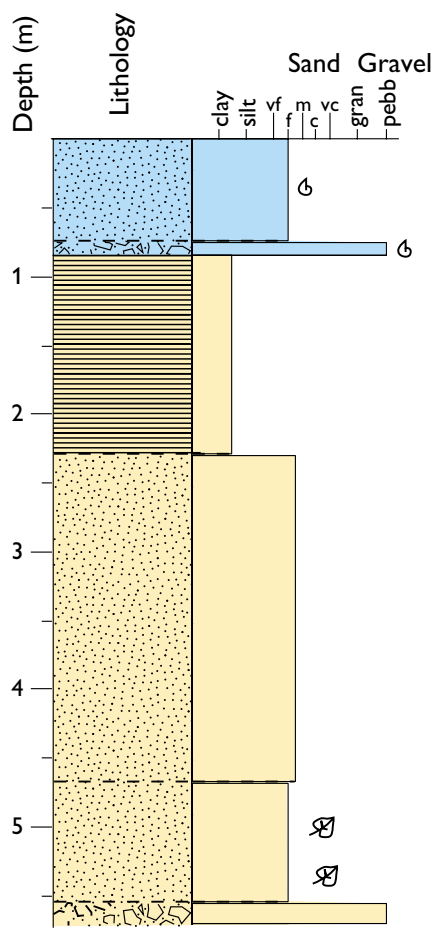

Fig. 2. Lithological logs of core NS 12-2-13 and NS 12-3-09. NS 12-2-13 was sampled at a water depth of $32.0 \mathrm{~m}$ and core NS 12-3-09 was sampled at a water depth of $43.5 \mathrm{~m}$. Blue: Marine Holocene. Yellow: non-marine pre-Holocene. sample of Salix herbacea leaves gave an age of $c .12 .6 \mathrm{cal}$. ka BP, corresponding to a Younger Dryas age (Table 1).

Younger Dryas deposits are common in Denmark, and several submarine deposits from inner Danish waters have also been found (e.g. Bennike et al. 2004; Bennike \& Jensen

Table 2. Macrofossils of Weichselian age from the North Sea

\begin{tabular}{|c|c|c|}
\hline & $\begin{array}{l}\text { NS } 12-2-13 \\
\text { c. } 12.6 \mathrm{ka}\end{array}$ & $\begin{array}{c}\text { NS } 12-3-09 \\
\text { c. } 35 \mathrm{ka}\end{array}$ \\
\hline \multicolumn{3}{|l|}{ PLANTS } \\
\hline Cenococcum geophilum sclerotia & 3 & 15 \\
\hline Distichium sp. stems & - & 1 \\
\hline Ditrichum sp. stem & - & 4 \\
\hline Bryum sp. stems & - & $r$ \\
\hline Paludella squarrosa stem & - & 1 \\
\hline Drepanocladus revolvens stems & - & 2 \\
\hline Drepanocladus s.l. sp. stems & c & $r$ \\
\hline Scorpidium scorpioides stems & c & r \\
\hline Polytrichum sp. leaves & 1 & 3 \\
\hline Selaginella selaginoides megaspores & 1 & 1 \\
\hline Ranunculus sp. achene & 1 & - \\
\hline Betula nana leaf fragment & 1 & - \\
\hline Salix herbacea leaves & 7 & 16 \\
\hline Salix phylicifolia leaves & 2 & - \\
\hline Dryas octopetala leaves & - & 11 \\
\hline Empetrum nigrum endocarps & 4 & - \\
\hline Juncus sp. seed & - & 1 \\
\hline Carex spp. achenes & 6 & 14 \\
\hline Potamogeton filiformis achenes & - & 3 \\
\hline \multicolumn{3}{|l|}{ ANIMALS } \\
\hline Cladocera indet. shells & - & r \\
\hline Staphylinidae indet. wing & 1 & - \\
\hline Chironimidae indet. head capsules & - & $r$ \\
\hline Trichoptera indet. sclerite & - & 1 \\
\hline Oribatida indet. skeletons & - & $r$ \\
\hline Fredericella indica statoblast & 1 & - \\
\hline Cristatella mucedo statoblast & 1 & - \\
\hline
\end{tabular}




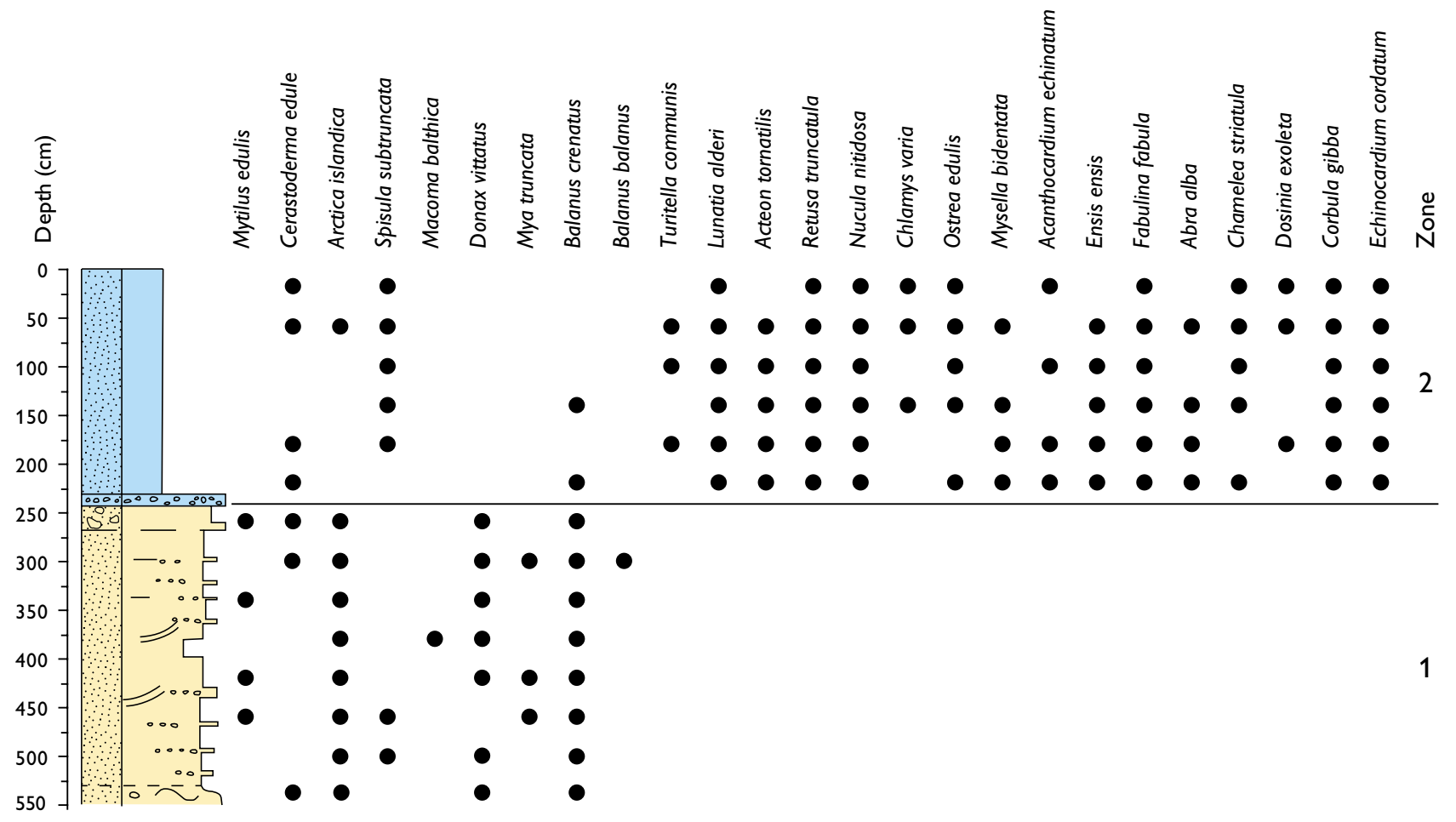

Fig. 3. Simplified macrofossil diagram of core 562028 from Jyske Rev (see Fig. 1 for location). Blue: Holocene marine fine-grained sand. Yellow: PreHolocene medium- and coarse-grained sand with pebbles.

2011; Mortensen et al. 2014). However, the present article is the first that reports on a Younger Dryas deposit from the Danish part of the North Sea. The deposit shows that the coring site had not yet been transgressed by the sea.

\section{A Middle Weichselian deposit}

Core NS 12-3-09 consists of $75 \mathrm{~cm}$ of Holocene marine finegrained sand, underlain by $10 \mathrm{~cm}$ of Holocene marine gravel, $145 \mathrm{~cm}$ clay and silt, $238 \mathrm{~cm}$ fine- and medium-grained sand, $87 \mathrm{~cm}$ fine-grained sand with plant remains and $15 \mathrm{~cm}$ gravel.

Remains of terrestrial plants include leaves of Salix herbacea, leaves of Dryas octopetala, a megaspore of Selaginella selaginoides, 2 stems with leaves of Ditrichum sp., 1 stem with leaves of Distichium sp. and sclerotia of Cenococcum geophilum (Table 2). Wetland species are represented by Carex sp., Juncus sp., Scorpidium scorpioides, Drepanocladus revolvens and Paludella squarrosa. Lake or pond species are represented by Potamogeton filiformis, and freshwater invertebrates are represented by cladocerans, chironomid larvae and Trichoptera. A sample of $S$. herbacea and D. octopetala leaves gave an age of $c .35$ cal. ka BP, corresponding to a Middle Weichselian age - prior to the last glacial maximum (Table 1).

Most of the species are known from Middle Weichselian deposits in Denmark, and indicate an open, treeless, tundra- like environment with wetlands and lakes. $S$. herbacea grows in areas with a long-lasting snow cover, whereas $D$. octopetala prefers areas with little snow cover. The presence of both of these dwarf shrubs indicates that wind-swept hills and places where snow could accumulate were present in the area.

Non-marine Middle Weichselian deposits with organic remains are rare in Denmark. Deposits of broadly the same age as the deposit from the North Sea have been discussed by Bennike et al. $(1994,2007)$ and Houmark-Nielsen et al. (1996); in addition, a number of re-deposited mammal bones and teeth, especially of mammoth (Mammuthus primigenius) have been found. The flora and fauna from the other Danish sites are similar to those from the North Sea. The Ålesund interstadial in south-west Norway, dated to 28-35 cal. ka BP, is characterised by an Arctic vertebrate fauna.

\section{Pre-Holocene bivalve shells and bones}

As mentioned in the introduction, dating of pre-Holocene marine shells from two cores from Jyske Rev gave ages of 43-45 cal. ka BP (Table 1; Leth 1998). Two of the dated species are boreal and warmth-demanding, which contrasts with indications of Arctic conditions during the same time period, as seen in other records from the region. A number 
of samples from the two cores were analysed in connection with this study.

The studied fauna includes a number of boreal species (Fig. 3, zone 1). In addition to Donax vittatus and Spisula subtruncata reported by Leth (1998), boreal species are also represented by Arctica islandica and Cerastoderma edule. These four species are known from Holocene and Eemian deposits in the region, but not from Weichselian deposits. The fauna from the cores also comprises Macoma balthica, Macoma calcarea, Mytilus edulis, Hiatella arctica, Mya truncata, Balanus crenatus and Balanus balanus that are boreal and Arctic. No species that are confined to the Arctic were found, and the fauna can be characterised as of interglacial type. The fauna in zone 2 is typical for Holocene fine-grained deposits in the region.

There are no reports of interglacial-type deposits from the region from the Middle Weichselian. For example, in France where the nearest continuous Weichselian deposits are found, the Middle Weichelian was characterised by open vegetation with cold-adapted beetles. Hence we suggest that the pre-Holocene fauna from Jyske Rev is of Eemian age. That means that the radiocarbon dates should be considered minimum ages. There are numerous examples in the literature of interglacial shells that have yielded non-finite radiocarbon ages which are usually assigned to post-mortem recrystallisation. The deposits with the pre-Holocene shells consist of medium- and coarse-grained sand and fine-grained gravel. During periods of low relative sea level, these sandy deposits may have been subject to groundwater flow, which could lead to recrystallisation and introduction of younger carbon.

In some areas of the Dutch sector of the North Sea, bones of cold-adapted mammals are common. The fauna includes terrestrial species such as mammoth (Mammuthus primigenius), musk-ox (Ovibos moschatus) and reindeer (Rangifer tarandus), but also marine species such as walrus, white whale (Delphinapterus leucas) and bearded seal (Erignatus barbatus). Radiocarbon dating of bones from marine mammals yielded Middle Weichselian ages and non-finite ages (Post 2005). We suggest that the finite ages should also be regarded as minimum ages, because we find it doubtful that the sea extended this far south during the Middle Weichselian, when the global sea level was much lower than at present. We consider it likely that Arctic marine mammals lived in the southern North Sea during the Early Weichselian.

\section{Summary}

During parts of the Weichselian, parts of the Danish North Sea were land with an open, treeless, tundra-like environment with wetlands and lakes. Two radiocarbon-dated Arctic floras are dated to the Younger Dryas and the Middle Weichselian. A marine fauna from Jyske Rev gave non-finite Middle Weichselian ages and we conclude that it is an interglacial-type fauna probably of Eemian age.

\section{Acknowledgement}

The mapping of sand and graval deposits was funded by the Danish Nature Agency.

\section{References}

Bennike, O. \& Jensen, J.B. 2011: Postglacial, relative shore-level changes in Lillebælt, Denmark. Geological Survey of Denmark and Greenland Bulletin 23, 37-40.

Bennike, O., Houmark-Nielsen, M., Böcher, J. \& Heiberg, E.O. 1994: A multi-disciplinary macrofossil study of Middle Weichselian sediments at Kobbelgård, Møn, Denmark. Palaeogeography, Palaeoclimatology, Palaeoecology 111, 1-15.

Bennike, O., Jensen, J.B., Lemke, W., Kuijpers, A. \& Lomholt, S. 2004: Late- and postglacial history of the Great Belt, Denmark. Boreas 33, 18-33.

Bennike, O., Houmark-Nielsen, M. \& Wiberg-Larsen, P. 2007: A Middle Weichselian interstadial lake deposit on Sejerø, Denmark: macrofossil studies and dating. Journal of Quaternary Science 22, 647-651.

Houmark-Nielsen, M., Bennike, O. \& Björck, S. 1996: Terrestrial biotas and environmental changes during the late Middle Weichselian in north Jylland, Denmark. Bulletin of the Geological Society of Denmark 43, 169-176.

Knudsen, K.L. 1985: Foraminiferal stratigraphy of Quaternary deposits in the Roar, Skjord and Dan fields, central North Sea. Boreas 14, 311-324.

Larsen, N.K., Knudsen, K.L., Krohn, C.F., Kronborg, C., Murray, A.S. \& Nielsen, O.B. 2009: Late Quaternary ice sheet, lake and sea history of southwest Scandinavia - a synthesis. Boreas 38, 732-761.

Leth, J.O. 1998: Late Quaternary geology and recent sedimentary processes of the Jutland Bank region, NE North Sea, 173 pp. Unpublished $\mathrm{PhD}$ thesis, University of Aarhus, Denmark.

Möhl, U. 1985: The walrus, Odobenus rosmarus (L.), as a "Danish" faunal element during the Weichsel Ice Age. Bulletin of the Geological Society of Denmark 34, 83-85.

Mortensen, M.F., Henriksen, P.S. \& Bennike, O. 2014: Living on the good soil: relationships between soils, vegetation and human settlement during the late glacial. Vegetation History and Archaeobotany 23, 195-205.

Post, K. 2005: A Weichselian marine mammal assemblage from the southern North Sea. Deinsea 11, 21-27.

\section{Authors' address}

Geological Survey of Denmark and Greenland, ØsterVoldgade 10, DK-1350 Copenhagen K, Denmark. E-mail: obe@geus.dk 